\title{
SOME OBSERVATIONS ON THE COAGULATION DEFECT IN VITAMIN K DEFICIENCY
}

\author{
BY \\ A. S. DOUGLAS \\ From the University Department of Medicine, Royal Infirmary, Glasgow
}

(RECEIVED FOR PUBLICATION DECEMBER 11, 1957)

The coagulation defect produced by the coumarin drugs has been studied in recent years in great detail, but disturbance in the clotting mechanism produced by vitamin-K deficiency has been investigated to a much less extent. In everyday clinical practice a clotting disorder due to vitamin-K deficiency is now less common than that therapeutically induced by the use of coumarin or allied drugs.

It is generally accepted that the "hypoprothrombinaemia "produced by the coumarin drugs has a duel facet-a deficiency of prothrombin, the precursor of thrombin, and a deficiency of factor VII, a component required to react with tissue in the formation of extrinsic thromboplastin. It is also usually agreed that the serum of patients on the coumarin drugs has a defective reaction in the thromboplastin generating system, when interacted with normal adsorbed plasma and platelets.

It is the object of this paper to present evidence confirming that the vitamin $\mathrm{K}$ defect has the same features as those produced by the coumarin drugs and to show that at least one component of the blood thromboplastin defect is a deficiency of Christmas factor. This present study is complementary to recently reported observations (Douglas and Mair, 1957) of the Christmas factor defect in coumarin drug therapy.

\section{Methods}

Collection of Specimens.-Only specimens of blood obtained by clean venepuncture were used. The needles were of wide bore (s.w.g. No. 18). The syringes were allowed to fill without traction on the barrel and blood was collected therefore without frothing. For the preparation of plasma, venous blood was mixed with $3.8 \%$ sodium citrate in the proportion of nine parts of blood to one part of citrate, using graduated centrifuge tubes. For the preparation of serum, $10 \mathrm{ml}$. of venous blood was allowed to clot at room temperature in plain conical glass centrifuge tubes. The clotted blood was then stood in a water-bath at $37^{\circ} \mathrm{C}$. for two hours and the serum separated by centrifugation.

Centrifugation.-This was carried out at $4^{\circ} \mathrm{C}$. in a refrigerated centrifuge.

Glassware-All the clotting times of fibrinogen or plasma were carried out in tubes of $\frac{1}{2}$ in. internal diameter maintained at $37^{\circ} \mathrm{C}$.

Preparation of Reagents. - Human brain extract was prepared as described by Brown and Douglas (1952). $M / 40$ and $M / 10$ calcium chloride, $3.8 \%$ sodium citrate, aluminium hydroxide (alumina), and human fibrinogen were all prepared as described by Biggs and Macfarlane (1953).

Blood Examinations.-The whole blood coagulation time, the one-stage " prothrombin " time, recalcification time, and the tourniquet test were carried out by techniques described by Biggs and Macfarlane (1953).

The bleeding time was determined by Ivy's technique as described by O'Brien (1951). The platelet count was performed as described by Dacie (1956), and the factor $\mathrm{V}$ assay as described by Douglas and Biggs (1953) and Douglas (1956).

Thromboplastin Generation Test and Thromboplastin Dilution Curve.-These were done as described by Biggs and Douglas (1953) except that the serum was prepared as described above.

Two-stage Prothrombin Assay. - The globulin fraction technique as described by Douglas and Biggs (1953) was used.

Factor VII Assay. - This was determined as described by Douglas and Davies (1955) similarly to the method described by Biggs and Macfarlane (1953). The substrate plasma was obtained from patients on phenindione.

Prothrombin Consumption Technique.-Two procedures were used: $(a)$ On whole blood as described by Douglas and Biggs (1953); $(b)$ on recalcified plasma, being a comparison of the ability of normal or vitamin-K deficient plasma to correct the defective prothrombin consumption of recalcified Christmas disease plasma. 
Citrated blood was collected from patients severely affected with Christmas disease. This blood was "low spun " at 500 r.p.m. for $20 \mathrm{~min}$. and the plateletrich plasma separated. The blood after removal of the "low-spun" plasma was centrifuged at 10,000 r.p.m. for five minutes on a high-speed head attachment. The resulting "high-spun "Christmas disease plasma was then added to the "low-spun" plasma. This manœuvre was designed to conserve the Christmas disease plasma.

"Low-spun" Christmas disease plasma, $0.5 \mathrm{ml}$., was delivered to each of 36 tubes. To 12 of these tubes (series A) was added a standard quantity of normal plasma, $0.05 \mathrm{ml}$; a similar addition of vitamin-Kdeficient plasma was added to a further 12 tubes (series B); a similar addition of Christmas disease plasma was added to the third set of 12 tubes (series C). For each of these three series of tubes (A, B, and C) there were 12 tubes containing $0.2 \mathrm{ml}$. saline, $0.2 \mathrm{ml}$. of brain, and $0.2 \mathrm{ml}$. M/40 calcium chloride and 24 tubes containing $0.2 \mathrm{ml}$. of fibrinogen. The tubes in each series (A, B, or C) were recalcified almost simultaneously with $0.125 \mathrm{ml}$. M/10 calcium chloride. At intervals of five minutes after recalcification one tube in each series was tested. Any fibrin formed was removed on a wooden applicator stick and $0.2 \mathrm{ml}$. added to the saline-brain-calcium tube. At this point a stop-watch was started, and at 45 seconds and 90 seconds thereafter $0.1 \mathrm{ml}$. was added to a $0.2 \mathrm{ml}$. amount of fibrinogen and the clotting time recorded.

\section{Results}

Two patients with vitamin $\mathrm{K}$ deficiency were studied.

The first was a 39-year-old woman with longstanding obstructive jaundice and a secondary steatorrhoea. Six years previously she had been operated upon for gall stones, the common bile duct ligated and divided, and a cholecystgastrostomy performed. Subsequently she developed jaundice and a further three operations were performed in attempts to provide drainage of bile into the upper intestinal track. These failed and she had in consequence obstructive jaundice and steatorrhoea. In consequence she developed typical deficiencies, night blindness, tetany, osteoporosis, and some haemorrhagic phenomena, menorrhagia, haematemesis, spontaneous bruising.

The whole blood coagulation time, bleeding time, tourniquet test, recalcification time, platelet count, and the factor $\mathrm{V}$ assay all gave normal results.

The one-stage "prothrombin" time was $27 \mathrm{sec}$. in the patient and $15 \mathrm{sec}$. in a control (Table I).

Thromboplastin Generation Technique.-The adsorbed patient's plasma was normal in the system. The serum gave a defective reaction (see Table II). In this table also is shown the failure of vitamin-Kdeficient serum and phenindione serum to be mutually corrective.
TABLE I

ONE-STAGE “PROTHROMBIN” TIME, ASSAYS OF FACTOR VII, AND PROTHROMBIN

\begin{tabular}{|c|c|c|c|c|}
\hline & $\begin{array}{l}\text { Time after } \\
\text { Giving } \\
\text { Vitamin } \mathrm{K}_{1} \text {, } \\
\text { etc. (hr.) }\end{array}$ & $\begin{array}{l}\text { One-stage } \\
\text { "Pro- } \\
\text { thrombin" } \\
\text { Time (sec.) }\end{array}$ & $\begin{array}{l}\text { Factor VII } \\
\text { Assay }(\%)\end{array}$ & $\begin{array}{c}\text { Two-stage } \\
\text { Prothrombin } \\
\text { Assay } \\
(\%)\end{array}$ \\
\hline $\begin{array}{c}\text { Patient } \\
\text { (1) }\end{array}$ & $\begin{array}{rll}0 & \ldots & \ldots \\
3 & \ldots & \ldots \\
6 & \ldots & \cdots \\
9 & \ldots & \ldots \\
14 & \ldots & \ldots \\
24 & \ldots & \ldots \\
\text { Control } & \ldots \\
\text { Phenindione }\end{array}$ & $\begin{array}{l}27 \\
22 \\
20 \\
18 \\
16 \\
14 \\
15 \\
41\end{array}$ & $\begin{array}{r}5 \\
8 \\
16 \\
32 \\
45 \\
100\end{array}$ & $\begin{array}{r}55 \\
70 \\
76 \\
86 \\
90 \\
100\end{array}$ \\
\hline $\begin{array}{c}\text { Patient } \\
\text { (2) }\end{array}$ & $\begin{array}{c}0 \\
24\end{array}$ & $\begin{array}{r}270 \\
15\end{array}$ & $\begin{array}{c}\text { No factor VII } \\
\text { present } \\
100\end{array}$ & $\begin{array}{r}16 \\
100\end{array}$ \\
\hline
\end{tabular}

* The available phenindione plasma had a shorter " one-stage clotting time than the patient.

Two-stage Prothrombin Assay.-This gave a result $55 \%$ of normal.

Effect of Vitamin K.-In Tables I and II are shown the estimations of serial specimens collected at intervals after the administration of $50 \mathrm{mg}$. vitamin $K_{1}$ intravenously. The effect is shown on the one-stage "prothrombin " time, on the prothrombin assay, on the factor VII assay (see Table I), on the serum thromboplastin activity, and on the ability of the serum to correct the serum thromboplastin defect in Christmas disease serum (see Table II).

These results show the lowered concentration of prothrombin and factor VII and the impaired ability of the serum to react in the thromboplastin generating system. The impaired ability to correct the defective serum reaction of Christmas disease serum is also illustrated. The rapid correction of these abnormalities following the administration of vitamin $\mathrm{K}_{1}$ is demonstrated.

The second patient was a 59-year-old woman known to be suffering from steatorrhoea for three years before the admission during which this study was carried out. She was readmitted on this occasion with extensive spontaneous bruising of the left arm, left shoulder, and over the anterior chest wall.

The bleeding time, tourniquet test. platelet count, and factor $\mathrm{V}$ assay were all normal.

The whole blood coagulation time was more than one hour.

Prothrombin Consumption.- There was no coagula-

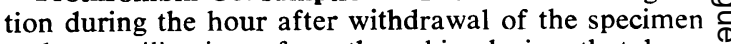
and no utilization of prothrombin during that hour $\stackrel{\mathcal{\Phi}}{\rightarrow}$ using the technique of Douglas and Biggs (1953). The clotting times obtained from the globulin fractions were as follows:

\begin{tabular}{c|c|c|c|c|c}
\hline $\begin{array}{c}\text { Normal } \\
\text { Plasma }\end{array}$ & $\begin{array}{c}\text { Patient's } \\
\text { Plasma }\end{array}$ & $\frac{1}{4}$ Hour & $\frac{1}{2}$ Hour & $\frac{1}{1}$ Hour & 1 Hour \\
\cline { 1 - 3 } & $92 \mathrm{sec}$. & $98 \mathrm{sec}$. & $90 \mathrm{sec}$. & $86 \mathrm{sec}$. & $97 \mathrm{sec}$. \\
\hline
\end{tabular}


TABLE II

OBSERVATIONS ON THE THROMBOPLASTIN GENERATION TECHNIQUE

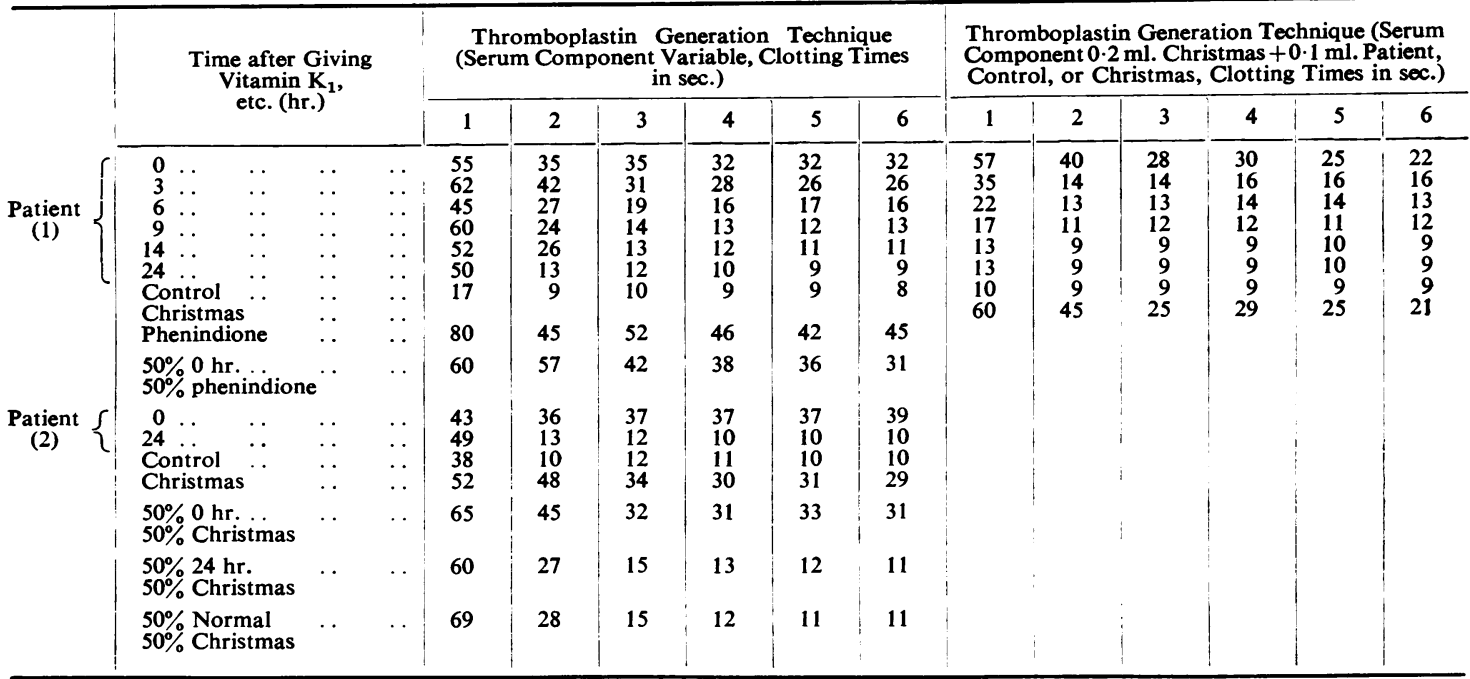

The one-stage " prothrombin" time was $270 \mathrm{sec}$. compared with $15 \mathrm{sec}$. in a control.

Thromboplastin Generation Technique. - The absorbed patient's plasma was normal in the system, but the serum gave a defective reaction (see Table II). The patient's serum was unable to correct the thromboplastin defect in Christmas serum.

Two-stage Prothrombin Assay.-As shown in Table I, there was $16 \%$ of prothrombin present.

Effect of Vitamin K.-In Tables I and II it will be seen that before the administration of the vitamin $\mathbf{K}$ there was reduced concentration of prothrombin, factor VII, and impaired serum thromboplastin activity and ability to correct the serum thromboplastin defect in Christmas disease. These facets of the defect had been corrected in the specimen examined 24 hours after giving vitamin $K_{1}$.

Failure to Correct Recalcification Time of Christmas Disease Plasma.-The impaired ability of this patient's plasma (before giving vitamin $\mathbf{K}_{1}$ ) to correct the prolonged recalcification time of Christmas disease plasma is demonstrated (Table III). There is normal ability to correct the haemophilic defect.
TABLE III

RECALCIFICATION TIMES OF PLASMA FROM NORMAL VITAMIN-K-DEFICIENT PATIENT (CASE 2), HAEMOPHILIAC, AND CHRISTMAS DISEASE

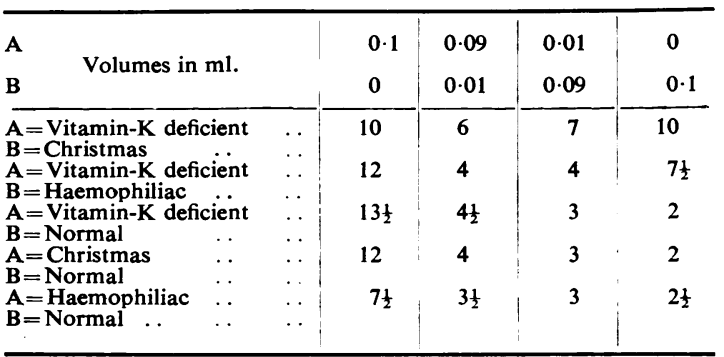

Clotting times to the nearest half-minute.

Failure to Correct Defective Prothrombin Consumption of Recalcified Christmas Disease Plasma.The results are shown in Table IV. It will be seen that in comparison with the normal there was very considerable impairment in the ability of the vitamin$\mathrm{K}$ deficient plasma to correct the defective prothrombin utilization of Christmas disease plasma.

TABLE IV

PROTHROMBIN CONSUMPTION OF RECALCIFIED CHRISTMAS PLASMA WITH ADDITIONS OF NORMAL AND PATIENT (2) PLASMA

\begin{tabular}{|c|c|c|c|c|c|c|c|c|c|c|c|c|c|}
\hline $\begin{array}{l}\text { Christmas } \\
\text { Plasma }\end{array}$ & $\begin{array}{l}\text { Incubation } \\
\text { Time (sec.) }\end{array}$ & $5^{\prime}$ & $10^{\prime}$ & $15^{\prime}$ & $20^{\prime}$ & $25^{\prime}$ & $30^{\prime}$ & $35^{\prime}$ & $40^{\prime}$ & $45^{\prime}$ & $50^{\prime}$ & $55^{\prime}$ & $60^{\prime}$ \\
\hline+ Normal . . & $\begin{array}{l}45 \\
90\end{array}$ & $\begin{array}{l}10 \\
12\end{array}$ & $\begin{array}{l}45 \\
63\end{array}$ & $\begin{array}{l}65 \\
81\end{array}$ & $\begin{array}{l}61 \\
69\end{array}$ & $\begin{array}{l}87 \\
94\end{array}$ & $\begin{array}{l}88 \\
94\end{array}$ & $\begin{array}{l}104 \\
113\end{array}$ & $\begin{array}{l}117 \\
141\end{array}$ & $\begin{array}{r}96 \\
122\end{array}$ & $\begin{array}{r}96 \\
117\end{array}$ & $\begin{array}{r}92 \\
110\end{array}$ & $\begin{array}{l}104 \\
117\end{array}$ \\
\hline $\begin{array}{r}\text { Vitamin-K } \\
\text { deficient }\end{array}$ & $\begin{array}{l}45 \\
90\end{array}$ & $\begin{array}{l}11 \\
14\end{array}$ & $\begin{array}{r}9 \\
11\end{array}$ & $\begin{array}{l}10 \\
11\end{array}$ & $\begin{array}{l}11 \\
14\end{array}$ & $\begin{array}{l}15 \\
19\end{array}$ & $\begin{array}{l}16 \\
20\end{array}$ & $\begin{array}{l}16 \\
22\end{array}$ & $\begin{array}{l}15 \\
20\end{array}$ & $\begin{array}{l}17 \\
19\end{array}$ & $\begin{array}{l}23 \\
26\end{array}$ & $\begin{array}{l}20 \\
23\end{array}$ & $\begin{array}{l}19 \\
24\end{array}$ \\
\hline +Christmas & $\begin{array}{l}45 \\
90\end{array}$ & $\begin{array}{l}12 \\
14\end{array}$ & $\begin{array}{l}12 \\
15\end{array}$ & $\begin{array}{l}10 \\
14\end{array}$ & $\begin{array}{l}10 \\
11\end{array}$ & $\begin{array}{l}13 \\
16\end{array}$ & $\begin{array}{l}12 \\
14\end{array}$ & $\begin{array}{l}14 \\
17\end{array}$ & $\begin{array}{l}12 \\
14\end{array}$ & $\begin{array}{l}13 \\
16\end{array}$ & $\begin{array}{l}19 \\
21\end{array}$ & $\begin{array}{l}14 \\
18\end{array}$ & $\begin{array}{l}19 \\
26\end{array}$ \\
\hline
\end{tabular}




\section{Discussion}

This investigation has confirmed the prothrombin-factor-VII defect in vitamin $\mathrm{K}$ deficiency. The thromboplastin defect has been studied in some detail. There is a defective serum reaction in vitamin $\mathbf{K}$ deficiency on the thromboplastin generation test and failure of mutual correction with Christmas disease serum in this test system. Since serum is an end-product of the coagulation process, this failure of mutual correction could theoretically represent a common defect reached through different channels. New evidence has been produced in this investigation to show that the failure of the two sera to correct is indeed due to a Christmas factor defect in the vitamin-Kdeficient blood. The failure adequately to correct the prolonged recalcification time of Christmas disease plasma gives some support to the concept. The failure of the vitamin-K-deficient plasma to correct the defective prothrombin consumption of recalcified Christmas disease plasma is convincing evidence. The results of this test cannot be due to the prothrombin deficiency of the vitamin-Kdeficient plasma, since the addition of normal plasma with a normal prothrombin content to the test system results in less residual prothrombin. Since recent evidence indicates that factor VII is not concerned in blood thromboplastin formation, and since the Christmas plasma has a normal content of factor VII, the results cannot reasonably be attributed to the difference in the content of factor VII of the addition.

The administration of vitamin $\mathrm{K}$ corrects all the facets of the defect, namely, prothrombin deficiency, factor VII deficiency, the serum thromboplastin defect, and the ability of the serum to correct the thromboplastin defect in Christmas disease serum. The rate of correction of each of these properties is essentially similar. Prothrombin, factor VII, and the Christmas factor have many properties in common. They are all adsorbed by inorganic precipitates, are all deficient in coumarin therapy (Naeye, 1956 ; Sise, Kimball, and Adamis, 1955 ; Douglas and Mair, 1957), and by this study are shown all to be reduced in concentration in vitamin $\mathrm{K}$ deficiency, responding at similar rates to the administration of vitamin $\mathbf{K}$. The possibility is further raised that these three components may be more closely identified than is generally envisaged.

The defects produced by vitamin $\mathbf{K}$ deficiency and that produced by the coumarin drugs have identical features.

Telfer, Denson, and Wright (1956) and Hougie, Barrow, and Graham (1957) have described cases of constitutional haemorrhagic disease with a pro- longed one-stage test and defective serum reaction 을 in the thromboplastin generation system. These $\overrightarrow{\bar{N}}$ abnormal laboratory findings are believed not to $\frac{\pi}{0}$ be attributable to deficiencies of factor VII or the $\frac{\square}{5}$ Christmas factor and have been called respectively $\frac{\bar{\sigma}}{\bar{s}}$ the Prower defect (Telfer et al., 1956) and the $\vec{\nabla}$ Stuart defect (Hougie et al., 1957). Since neither $\stackrel{\circ}{2}$ of these two defects corrects the coumarin defect $\%$ adequately, it is possible that the interpretation $\overrightarrow{0}$ of the experimental phenomena described in this paper is incomplete.

\section{Summary}

Evidence is described indicating a deficiency of $\overrightarrow{\vec{\omega}}$ the Christmas factor as part of the coagulation $\omega$ defect resulting from lack of vitamin K. This N deficiency of Christmas factor has been demon- $\overrightarrow{0}$ strated by the impaired ability of vitamin-K- $?$ deficient plasma to correct the defective prothrom- $\vec{z}$ bin consumption of recalcified Christmas disease plasma. Also ability to correct the prolonged recalcification time of Christmas disease plasma and $\bar{E}$ the serum thromboplastin defect in Christmas disease is impaired.

The reduced concentration of prothrombin and factor VII in vitamin $\mathbf{K}$ deficiency is confirmed.

The facets of the vitamin $\mathrm{K}$ defect (prothrombin, factor VII, serum thromboplastin $\stackrel{\unrhd}{\unrhd}$ defect, and the inability of serum to correct the $\overrightarrow{\vec{F}}$ Christmas serum thromboplastin defect) are the $\frac{0}{3}$ same as those resulting from the administration of the coumarin drugs. These components of the vitamin $\mathrm{K}$ defect all respond at similar rates to the administration of vitamin $\mathbf{K}$.

The author wishes to thank Professor L. J. Davis for his interest in this investigation and guidance in the preparation of this manuscript. The author is $\frac{3}{3}$ also indebted to Dr. J. H. Wright for permission to publish details of his case and to Miss K. Mair for valuable technical assistance. Part of the expenses of $D$ the equipment used in this work was defrayed by a grant from the Advisory Committee on Medical N Research for Scotland. The technical assistance wasfinanced by the Medical Research Council.

\section{REFERENCES}

Biggs, R., and Douglas, A. S. (1953). J. clin. Path., 6, 23 ond Muman Blood Coagulation and Its Disorders. Blackwell, Oxford.

Its Disorders. Blackwell, Oxford.
Brown, A., and Douglas, A. S. (1952). Glasg. med. J., 33, 225.

Dacie, J. V. (1956). Practical Haematology, 2nd ed. Churchill, London.

Douglas, A. S. (1956). Brit. J. Haemat., 2, 153

$\longrightarrow$ and Biggs, R. (1953). Glasg. med. J., 34, 329.

- and Davies, P. (1955). Arch. Dis. Childh., 30, 509.

and Mair, K. (1958). Clin. Sci. In press.

Hougie, C., Barrow, E. M., and Graham, J. B. (1957). J. clin Invest., 36, 485 .

Naeye, R. L. (1956). Proc. Soc. exp. Biol. (N.Y.), 91, 101.

O'Brien, J. R. (1951). J. clin. Path., 4, 272.
Sise, H.S., Kimball, D. M., and Adamis, D. (1955). Proc. Soc. exp. Biol. (N.Y.), 89, 81 .

Telfer, T. P., Denson, K. W., and Wright, D. R. (1956). Brit. JC Haemat., 2, 308. 